Q norden

Future solutions for Nordic plastic recycling 

2 norden 



\section{Future solutions for Nordic plastic recycling}

Anna Fråne, Åsa Stenmarck, Stefán Gíslason, Søren Løkke, Malin zu Castell Rüdenhausen, Hanne L Raadal and Margareta Wahlström

TemaNord 2015:509 
Future solutions for Nordic plastic recycling

Anna Fråne, Åsa Stenmarck, Stefán Gíslason, Søren Løkke, Malin zu Castell Rüdenhausen, Hanne L Raadal and Margareta Wahlström

ISBN 978-92-893-3947-6 (PRINT)

ISBN 978-92-893-3949-0 (PDF)

ISBN 978-92-893-3948-3 (EPUB)

http://dx.doi.org/10.6027/TN2015-509

TemaNord 2015:509

ISSN 0908-6692

(C) Nordic Council of Ministers 2014

Layout: Hanne Lebech

Cover photo: Signelements

Print: Rosendahls-Schultz Grafisk

Printed in Denmark

This publication has been published with financial support by the Nordic Council of Ministers. However, the contents of this publication do not necessarily reflect the views, policies or recommendations of the Nordic Council of Ministers.

\section{www.norden.org/en/publications}

\section{Nordic co-operation}

Nordic co-operation is one of the world's most extensive forms of regional collaboration, involving Denmark, Finland, Iceland, Norway, Sweden, and the Faroe Islands, Greenland, and Åland.

Nordic co-operation has firm traditions in politics, the economy, and culture. It plays an important role in European and international collaboration, and aims at creating a strong Nordic community in a strong Europe.

Nordic co-operation seeks to safeguard Nordic and regional interests and principles in the global community. Common Nordic values help the region solidify its position as one of the world's most innovative and competitive.

\section{Nordic Council of Ministers}

Ved Stranden 18

DK-1061 Copenhagen $\mathrm{K}$

Phone (+45) 33960200

www.norden.org 


\section{Content}

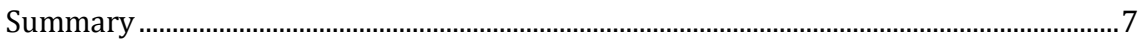

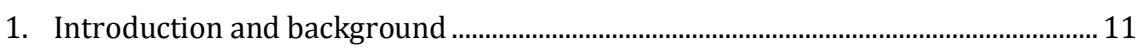

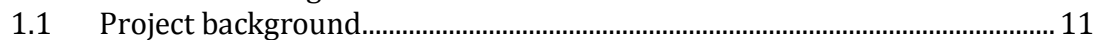

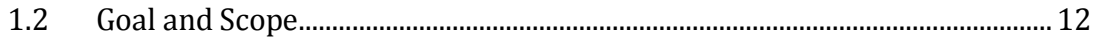

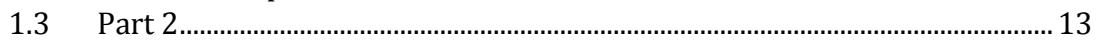

2. Future solutions for Nordic plastic recycling ............................................................. 15

$2.1 \quad$ Increased collection of plastic waste .............................................................. 15

2.2 Flexible sorting and recycling systems ............................................................ 26

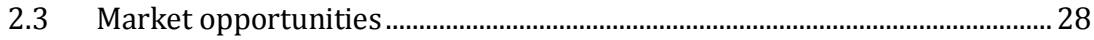

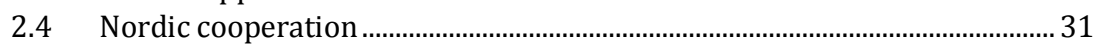

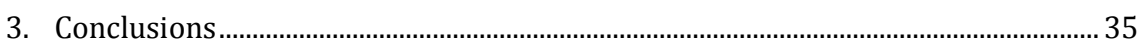

4. References............................................................................................................ 37

5. Appendix 1: Definitions used in the report ................................................................... 41

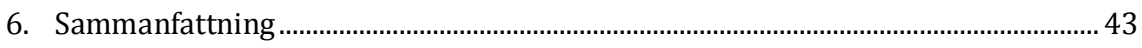





\section{Summary}

This report is the outcome of part two in the project Improvements in existing collection and recycling systems for plastic waste from households and other MSW sources initiated by the Nordic Waste Group (NWG). The project is carried out by five organisations covering different parts of the Nordic region: IVL Swedish Environmental Research Institute (project leader), Ostfold Research (Norway), VTT Technical Research Centre of Finland (Finland), Aalborg University (Denmark) and Environice (Iceland).

There is great potential in increasing the collection and recycling of plastic waste from households and other MSW in the Nordic region. The project group has identified the following future solutions in order to improve collection and recycling of plastic waste aiming for higher recycling rates.

This report is part of the Nordic Prime Minister's overall green growth initiative: "The Nordic Region - leading in green growth" - read more in the Nordic Council of Minister's web magazine Green Growth the Nordic Way at www.nordicway.org or at www.norden.org/greengrowth

\section{More collection through increased availability}

A condition to increase recycling of plastic is to collect more of the generated plastic waste in the dedicated collection and recycling systems, and thus avoid plastic waste in waste fractions to incineration.

Key to increased collected amounts seems to be availability for the consumers. Higher availability could be made by focusing on kerbside collection, a denser net of public drop-off points, and smaller drop-off points in public areas. To make it easier for other municipal sources than households (such as smaller companies) to get access to practical solutions, e.g. public drop-off points, could additionally help collecting more of the plastic waste generated. Combinations of solutions focusing on increased availability that take local conditions into consideration are required. This includes both source-separation of plastic waste as well as central sorting of a composition of mixed waste (incl. plastic waste). With the current market situation increased availability would result in increased costs, and could possibly be financed with adjusted packaging fees. 


\section{Less focus on packaging and more focus on plastic}

The generated amount of non-packaging small plastic items is small compared to discarded plastic packaging waste. Combined collection of packaging and non-packaging plastic could be advantageous from many angles. Non-packaging plastic waste is already found among plastic packaging waste fractions, and it is clear that many consumers are not aware of this distinction. Accepting non-packaging small plastic waste items among packaging might also lead to more positive side-effects and influence positively on consumer behaviour. Such a system is challenged by the fact that non-packaging plastic waste is a more heterogeneous stream than plastic packaging, both in relation to number of polymers used and in relation to content of undesired potential hazardous substances, impacts that need to be further analysed if such a solution is to be implemented. Also administrative and legal aspects would need to be analysed as well as the potential effects on the quality of the secondary plastic raw material.

\section{Flexible sorting and recycling systems}

Sorting and processing of plastic waste needs to be line with the incoming material composition and produce secondary plastic raw material that enables substitution of virgin plastics to the highest extent possible. "Static" sorting processes can hamper the trustworthiness of the collection and recycling systems if efforts to collect plastic waste are not paid off, i.e. if plastic waste collected is not in the end recycled. Changeable process units and continuous cooperation with material research and development are key features of a flexible recycling system. The responsibility and financing for securing sorting processes in line with upstream and downstream demand should be shared between actors in the value chain, e.g. that sorting/recycling companies could influence the product design.

\section{Market opportunities}

The market and the demand for recycled plastics, the final step in the value chain, is a strong driver for increased collection. Important for the overall environmental impact of plastic collection and recycling is that the secondary plastic material substitutes virgin plastics to a high extent, i.e. recycling into products of high quality. Recycling into products of high-quality requires collection and recycling systems that provide highquality secondary plastic raw material to the market. This calls for cooperation and communication in the value chain. Transparency in the value chain is equally important; manufacturers using recycled plastics need 
to know what they are buying, and get information similar to the information they receive when buying virgin plastics.

The use of recycled plastics is influenced by two economic drivers; the price of the recycled polymer compared to virgin polymer, and the cost of recycling compared to alternative forms of acceptable disposal. Policy instruments with focus on creating "a pull" towards increased use of recycled plastics could be further evaluated, such as including criteria on the use of recycled plastics in public procurement and giving economic incentives/advantages to product manufacturers using recycled plastics.

Recycling of plastics is also driven by production and consumption of plastic products. Almost half of the amount of plastic waste collected for recycling in the EU is exported. The export is heavily dependent on export to China. In depth details about the fate of the exported plastic waste when it reaches China is not justified by conclusive evidence. Such deepened knowledge would increase transparency, and in turn the trust in recycling of plastics. The other half of the collected amounts of plastic waste for recycling stays in the EU. Learning and sharing good examples from existing product manufacturers in the Nordic countries, and in the EU, using recycled plastics today could inspire and encourage to local market, decreasing the dependence on exports.

\section{Nordic cooperation}

All proposed future solutions to increase Nordic plastic recycling could benefit from more extensive Nordic cooperation. Cooperation at two levels would be possible: on a practical level and based on knowledge exchange including information sharing and benchmarking between the countries. Knowledge exchange would hopefully pave the way and provide conditions for more practical Nordic cooperation. Practical cooperation between the Nordic countries could lead to economy of scale, allowing for sorting and recycling more within the local markets.

Communication between the different activities/actors in the value chain does not seem to work efficiently. By "connecting the dots" it could be more clarified what the different actors can do/not do/would like to do, and where cooperation would be beneficial. A Nordic networking platform involving stakeholders in the entire value chain could create conditions for communication and future cooperation. Possible tasks for such a forum could be to develop common information to households about the benefits of plastics recycling based on Nordic knowledge to increase the trustworthiness of plastic recycling, aim for a common Nordic approach to calculate national recycling rates - to facilitate benchmarking between the Nordic countries, and to initiate improved dialogue between contracted sorting facilities/EPR organisations and their 
registrerad producers to share knowledge about products that due to their design are not possible to recycle in the existing collection and recycling systems. The network could be arranged by an independent organisation also acting as an umbrella organisation for the EPR organisations. Funds for the arrangement of the platform could be initiated as project financing and continue through member fees. In order to attract paying members the platform must give benefits to its members through for example increased markets, beneficial information exchange etc. Actors from across the value chain should be invited to the platform, including designers, production industry, waste management companies, processers and recyclers, public sectors (national/regional/ local) and the civil society. 


\section{Introduction and background}

This report is part of the second deliverable of the project Improvements in existing collection and recycling systems for plastic waste from households and other MSW sources. The report has been prepared by IVL Swedish Environmental Research Institute (Sweden), Ostfold Research (Norway), VTT Technical Research Centre of Finland (Finland), Aalborg University (Denmark) and Environice (Iceland). The project was initiated by the Nordic Waste Group (NWG).

Part 2 of the project has resulted in three separate reports, this document represents the last mentioned:

- Guidelines to increased collection of plastic packaging waste from households.

- Background information - Guidelines to increased collection of plastic packaging waste from households.

- Future solutions for Nordic plastic recycling.

\subsection{Project background}

A working group formed in 2010 by the Nordic Prime Ministers presented in 2011 their report on favourable areas for Nordic cooperation and future priorities within the area of green economic growth. The report contained eight specific target areas where a joint Nordic cooperation was considered beneficial for the Nordic countries. All of the target areas were accepted by the Nordic Prime Ministers and it was decided that the work should be carried out by the Nordic Council of Ministers. The green growth initiative launched by the Prime Ministers is called The Nordic Region - leading in green growth.

One of the eight priority areas was aiming at resource efficiency and life cycle thinking in the waste management sector. To realise the work under the target area, NWG was asked to develop a Nordic project activity. NWG initiated as a response the overall project Resource efficient recycling of plastic and textile waste. In 2012 a pre-study was carried out to explore the potential for increased recycling of plastic and textile waste in the Nordic region. 
NWG developed six associated projects based on the pre-study, three concerning plastic waste and three concerning textile waste. Improvements in existing collection and recycling systems for plastic waste from households and other MSW sources is one of the three plastic projects. The project has apart from the three reports listed above published the report Collection and recycling of plastic waste - Improvements in existing collection and recycling systems in the Nordic countries.

\subsection{Goal and Scope}

The overall aim of the project Improvements in existing collection and recycling systems for plastic waste from households and other MSW sources (part 1 and part 2) is to pave the way and provide conditions for more efficient collection and recycling of plastic waste from households and other MSW in the Nordic countries, striving towards higher recycling rates.

The project considers:

- Plastic packaging waste from households and other MSW sources.

- Plastic bulky waste from households and other MSW sources.

- Small plastic waste other than packaging from households and other MSW sources.

Other municipal waste sources commonly refer to waste generated by other sources than households, but with the same composition as household waste. In some Nordic countries the term household waste includes "similar waste" from businesses. An example of similar waste is waste generated in canteens.

Plastic bulky waste is large items of plastic waste that do not fit into bins and bags and therefore need different handling. Examples of plastic bulky waste are plastic garden furniture and buckets.

Non-packaging small plastic waste other than packaging is items that by its size fit into the same collection system as plastic packaging waste, e.g. toot brushes and dish brushes. For more definitions used in the report, see Appendix 1.

Waste classified as hazardous, WEEE (Waste Electrical and Electronic Equipment), waste from end-of-life vehicles, leisure boats and plastics from the agricultural sector are not included in the project. 


\subsection{Part 2}

The focus of Part 2 is based upon two pillars; to develop Nordic guidelines on plastic packaging waste collection from households, and to propose future solutions for how recycling of plastic waste under the scope of the project can increase. The guidelines is presented in a separate document and has the aim of inspiring and give recommendations on how plastic packaging waste can be collected, and how different aspects concerning collection of plastic packaging can be taken into account. The guidelines are based on Nordic experience in order to encourage knowledge transfer and to give examples of how plastic packaging waste is collected in the Nordic region. The target group for the guidelines is primarily municipalities or other actors involved in collection and recycling of plastic packaging waste from households.

The future solutions for Nordic plastic recycling are targeted for national and regional policy makers with the possibility to change the conditions for collection and recycling of plastic waste in the Nordic countries.

The proposed future solutions in this report are built upon Part 1 of the project. Part 1 included descriptions of the existing collection and recycling systems of plastic waste in the Nordic countries on a country level highlighting the differences between the systems in terms of practical, organisational, and financial means. The known plastic waste flows in the Nordic countries were also quantified as well as identified potentials for increased recycling. Possible future solutions were presented and discussed, which in part 2 have continued.

The results from the project have derived from analysis of existing literature sources, interviews with stakeholders and experience and knowledge from the partner organisations. Valuable project input was also received from two workshops organised within the overall project Resource efficient recycling of plastic and textile waste. The first workshop was held in November 2013 in Oslo, and the second in Copenhagen in October 2014. The focus of the first workshop was to receive input and acceptance for the project, whereas the aim for the second workshop was to anchor the project's results and conclusions. 



\section{Future solutions for Nordic plastic recycling}

The project group has identified three main conditions that need to be improved in order to increase recycling of plastic waste from households and other MSW sources in the Nordic countries:

- More of the generated plastic waste needs to be collected for recycling.

- Sorting of plastic waste needs to be effective, flexible, and generate secondary plastic raw material that meets the market demands.

- A market for secondary plastic raw material needs to exist and absorb the collected, sorted amounts of plastic waste to enable recycling into products to replace virgin plastics.

Possible future solutions related to the three conditions have been developed by the project group based on knowledge gained in both part 1 and part 2 of the project.

Work towards increased recycling of plastic waste would according to the project group be facilitated by improved Nordic cooperation within the field of collection and recycling of plastic waste. Possible platforms and cooperative initiatives are presented and discussed in a separate subchapter (2.4).

\subsection{Increased collection of plastic waste}

To collect more of the generated plastic waste from households and other MSW sources in the dedicated collection and recycling systems is an absolute condition to enhance plastic recycling. The actual collection, or the capturing of material, is the backbone of the collection and recycling system. If plastic waste is not collected for recycling it is obviously difficult to reach a satisfying level of recycling, no matter how technologically advanced the downstream sorting and recycling processes are.

Despite the fact that practical collection solutions (as presented in the guidelines) are developing in the Nordic countries, the majority of the 
plastic waste generated is incinerated as it ends up in waste fractions to incineration. Analyses from Denmark, Norway and Sweden show that between 9 and $21 \mathrm{~kg} /$ person, year plastic packaging waste still end up in the residual waste (Guidelines, page 14), representing a large potential for increased source-separation of plastic packaging waste. According to a Swedish study $60-90 \%$ of the generated plastic packaging waste from households ends up in residual waste (Dahlén et al. 2013).

Although, the exact theoretical potential in the form of plastic waste in MSW fractions not subject to recycling is difficult to quantify it has in part 1 of the project been estimated to be in the range of 700,000 tonnes of plastic waste per year. ${ }^{1}$ The potential for each detailed suggestion below is not possible to estimate quantitatively, but the project group believes that a basket of conclusions is needed in order to reduce the amounts of plastic waste to incineration and even landfill.

Apart from ending up in waste fractions not subject to recycling, plastic waste is in addition amongst the most common pieces of litter in the Nordic countries. Along the Swedish west coast plastic items are in fact the most common pieces of litter (in number), plastic bags are in the top as well as unidentified pieces of plastic and expanded polystyrene (EPS) (Keep Sweden Tidy, 2014). The pattern is similar for the coasts around the Baltic Sea where different kinds of unidentified pieces of plastics, plastic bottle caps and lids, plastic bags and foamed plastic (packaging and insulation) are on the top 5 list of the most common pieces of litter found on urban and rural beaches measured by beach litter monitoring. Land-based sources are believed to contribute more to the marine litter than offshore sources. Marine litter has social, economic and environmental consequences with impact on important ecosystem services and commercial activities (Keep Sweden Tidy et al. 2013).

Two strategies of collection can be seen in the Nordic region. One strategy is focused on improved source-separation and the other on collection of a composition of mixed waste (including plastic waste) followed by central sorting. Paper, glass and metal, in addition to garden waste, textiles, hazardous waste and WEEE are currently not part of the mixed waste fractions as brings systems exist for these waste types.

Source-separation of plastic waste in the Nordic countries are carried out in single streams or together with other recyclables. The basic prin-

${ }^{1}$ Including both packaging waste and non-packaging small plastic items. 
ciple is, however, that the consumers make an effort to sort their waste into a certain manner.

\subsubsection{Increased collection by source-separation of plastic waste}

Source-separation is one way towards higher collected amounts of plastic waste. Secondary plastic raw material for recycling produced in the Nordic countries dominantly comes from source-separated plastic waste.

The following solutions are possible in order to increase recycling by collecting source-separated plastic waste:

- Increased source-separation opportunities outside of households/people's homes.

Source-separation opportunities for household plastic waste are very much focused on the availability in households. This is relevant as the majority of the generated municipal plastic waste is likely to end up in people's homes. It thus seems logical to adapt the same behaviour everywhere, also outside of the homes, but such opportunities are today rather limited. Establishment of drop-off points in popular areas where lots of people do their daily business can be challenging due to the competition between other land use purposes. Smaller and perhaps mobile drop-off points at public places such as in parks, close to bus and metro stops, in shopping centres etc. can be part of the solution towards increased collection. As an example it seems illogical for a family picnicking in the park to take the waste back home for source-separation when/if there are highly available waste bins for mixed waste in the park.

It seems like a substantial amount of the waste thrown in public waste bins consists of plastic waste. In Malmö, Sweden, analyses of the waste discarded in public waste bins in streets, parks and in other public places showed that around $30 \%$ of the waste was plastic packaging waste. Malmö has tested source-separation modules (Figure 1) (sourceseparation into plastic packaging, paper packaging, coloured and transparent glass and residual waste) in public places with good results. The level of contamination in the fractions has proven to be less than $5 \%$ (Mattsson, 2014). At the same time as the modules were installed almost 150 citizens were interviewed in Malmö. More than 90\% said that they would source-separate their waste in public areas if it was more highly available. Similar results were obtained by interviews in Gothenburg) (Hedenstedt, 2014). 
Figure 1. Module for source-separation in Malmö, Sweden

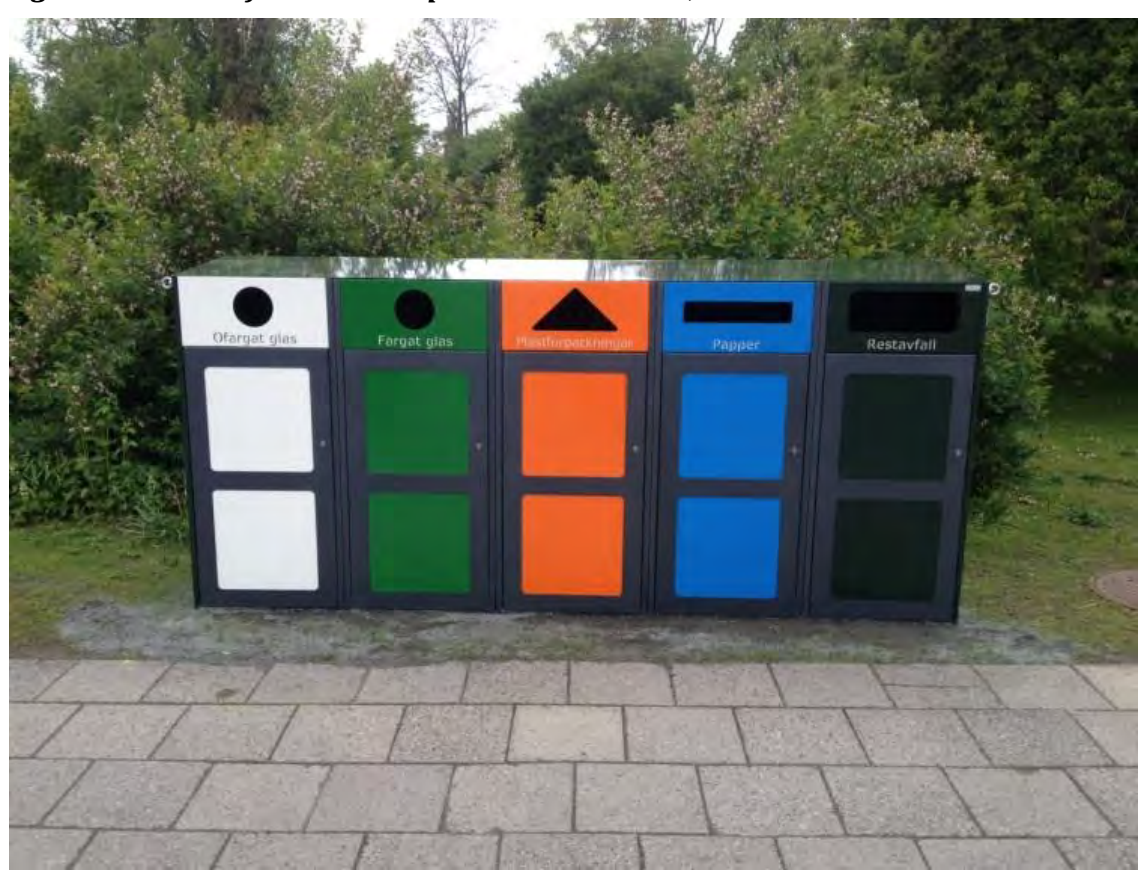

Source: Arne Mattsson.

Stockholm, Gothenburg, Malmö and Keep Sweden Tidy are carrying out a project looking into how source-separation modules can be uniformly designed in at least larger cities in Sweden. The project focuses on reducing littering and highlights the logic to source-separate in public places the same way as at home (Mattsson, 2014a).

Source-separation opportunities beyond kerbside collection and traditional bring systems are still in its infancy. The experience from Swedish municipalities so far is varying. The level of contamination is in some cases hindering recycling of the fractions, while other examples show an acceptable level of contamination. There are also examples where the results not yet have been analysed in depth (Mattsson, 2014b).

Experience of small-scale drop-off points from a Swedish municipality highlights that source-separation seems to work better in calm environment such as in parks or on beaches, that it is important to pay attention to the design of the small-scale drop-off stations/bins, and that it is clear where to throw the different fractions. The staff in charge of emptying the bins should be involved early in the implementation process. In addition, it is considered important that the fractions correspond to the fractions source-separated in the municipality in general, and that resources are dedicated to communication (Hedenstedt, 2014). 
- A denser net of public drop-off points and increased availability for source-separation of plastic waste at the kerb.

Kerbside collection and bring systems are sometimes seen as competing systems where the responsible actor need to decide on the best system for the municipality in question. The project group believes that both bring systems and kerbside collection for source-separated plastic waste are possible options, also in combination, the one does not exclude the other. It is not possible to tell where bring systems or kerbside collection systems are best suited, the local circumstances such as distances, way of living (mostly single family homes or apartment buildings) in the area, availability for waste trucks to get access, the organisation of other parts of the municipal waste management, and weather conditions are important factors, factors where the local actors have the best knowledge of what is possible to do and not do.

The emphasis, regardless of the collection system, should be put on increasing the availability to discard source-separated plastic waste. The existing bring systems is recommended to be seen in a perspective where the net of drop-off points are denser.

- Accept plastic waste from other municipal sources than households at public drop-off points.

Other municipal waste sources, such as small businesses (with waste similar to household waste) are in some areas of the Nordic region not allowed to use public drop-off points (for their consumer packaging). ${ }^{2}$ An example is a small business generating packaging waste in their canteen in Sweden. The company has to make arrangements with a waste contractor to make sure that their plastic packaging waste is recycled, or discard the packaging waste for free at one of around 100 drop-off stations, compared to around 6,000 drop-off points for households. The effort for relatively small generators of plastic packaging waste might be regarded as too heavy resulting in incinerated plastic packaging waste. In general, efforts are needed to facilitate for other MSW sources to get access to practical solutions and thereby increase the availability to discard plastic packaging waste.

2 Packaging assumed to be generated by households or other municipal waste sources with waste similar to household waste. 
Challenges to be investigated/solved for increased collection of plastic waste:

\section{Technical issues:}

The sorting capacity for source-separated plastic packaging waste in the Nordic countries is limited. Higher incoming amounts of plastic packaging waste must be taken into consideration.

\section{Economical issues:}

Increased collection of plastic packaging waste would with today's market situation lead to increased costs for the collection and recycling of plastic packaging waste. How these increased costs would be distributed depend on how the collection and recycling is organised. With the existing systems in the Nordic countries the extra costs could either be covered by higher packaging fees or by higher municipal waste management fees. If the collection is partly or entirely covered by municipal waste fees the final price tag depends on how the increased collection influences the municipal waste management in total, e.g. decreased waste amounts to incineration.

Higher packaging fees would with the current system be lead to higher consumer prices as the packaging fees are put on the products. The effect of higher plastic packaging fees on the national economies needs to be investigated. According to a Finnish report (FCG Consulting, 2010) the effect would thus be limited even though the costs are transferred to consumers. As an example, if bring systems for plastic packaging waste would be implemented in Finland (no existing system today) the price for a sausage packaging (5-40 g) would rise with EUR 0,0001-0,0004.

Allowing businesses to throw plastic packaging waste at public dropoff points might risk that business packaging, which is charged a lower packaging fee than consumer packaging, and where collection is not covered by the fees, end up there. The possibility to compensate for this by increasing the business plastic packaging fees is recommended to be explored.

\section{Other issues:}

Source-separation is challenged by the fact that consumers need to make an effort to contribute to the system, and thereby needs motivation to do so. The motivation must be so strong that plastic packaging waste is not thrown in residual waste fractions. Despite increased availability to discard source-separated plastic packaging there will always be a share of the population that is very difficult to motivate - even if they are able to discard their plastic packaging waste outside of their front door. In- 
creased availability is therefore part of the solution, but would probably require other instruments in combination. It is also worth mentioning and communicating the consumer's responsibilities to contribute to the collection and recycling systems.

The motivation for source-separation varies among the population, some source-separate to a very low extent while others source-separate meticulously. In between there are likely to be consumers that sourceseparate depending on the situation, on the type of plastic packaging waste, and on the content in the packaging. As source-separation of waste is strongly related to consumer behaviour, it is important to increase the knowledge about the motivators and the drivers behind certain behaviour, and what consumers need to source-separate. Are there certain types of plastic packaging waste that tend not to be source-separated? An on-going Swedish study will try to answer these questions. ${ }^{3}$

\subsubsection{Increased collection by combined collection of source-separated plastic packaging and non- packaging plastic waste}

Producer responsibility on plastic packaging waste has lead to EPR schemes with focus on plastic packaging, non-packaging plastic waste is not covered by the EPR schemes and thus not welcome in the system.

Despite this fact we know from a Swedish study that a third of the population (that was part in a material-based collection trial) throw non-packaging plastic waste in the same bin/container as plastic packaging waste (Naturvårdsverket, 2009). Other results from the study showed that the amount of non-packaging plastic waste is small in relation to plastic packaging waste why the increase in recycling would be limited if material-based collection was implemented. ${ }^{4}$ In Dahlén et al (2013) it was clear from the share of non-packaging plastic waste in the plastic packaging waste fraction (in average 16\%) that there is a willingness to sort out non-packaging plastic waste among the packaging.

The project group can identify a number of advantages with a collection system with less focus on packaging and more focus on plastic waste as a material. One of them, and probably the major one, is that such a collection system seems to be perceived logical to the waste gen-

\footnotetext{
3 The study is carried out by IVL Swedish Environmental Research Institute and Envir AB on behalf of Plastkretsen AB:s stiftelse för forskning. The project will be finalised in October 2015

$41-2 \%$ of the residual waste (Naturvårdsverket, 2009).
} 
erator. Speculatively, it is more logical to most of us to distinguish between plastic and other materials instead of packaging and nonpackaging plastic waste. It could also lead to positive side-effects and influence consumer behaviour and attitude towards source-separation, and increase the trust in waste management in general. Another advantage is that non-packaging plastic waste, as mentioned before, already is discarded among plastic packaging waste why the current collection and recycling systems are used to handling this type of mixture.

Challenges to be investigated/solved with combined collection of packaging and non-packaging plastics:

\section{Technical issues:}

Non-packaging plastic waste is a more heterogeneous stream than plastic packaging, both in relation to number of polymers used and in relation to content of undesired potential hazardous substances. The information about the content of hazardous substances in new items are lacking, and therefore also in products at their end-of-life. The available information is rarely transferred from producers, importers and fillers to the waste management operators. When hazardous substances are phased out in new products they can be available in old products for years and the knowledge about hazardous substances are often insufficient as well as its content (Kemikalieinspektionen, 2011).

Even though non-packaging plastic waste represent a small amount in relation to plastic packaging waste the risk of incoming hazardous substances would increase if material-based collection was imposed. Accepting non-packaging plastic waste also opens up for accepting smaller fractions of construction and demolition waste. The logic with material-based collection would be partly erased if too many instructions were communicated on what a non-packaging plastic item is. Apart from hazardous waste, the size would probably be the most suitable restricting factor.

The need to detect and separate plastic items with hazardous substances at existing sorting facilities would need to be investigated. Nonpackaging plastic waste does also contain a high variety of polymers, which need to be taken into account at the sorting facilities to enable recycling, and to not contaminate other fractions. Plastic packaging has a relatively short lifetime compared to many other non-packaging plastic items and its effects on the quality of the secondary plastic raw material would need to be analysed. Even though, not all polymers are detected and sorted out for recycling the benefit from the collection system being more logical to the households might weigh out this fact. 
In Norway where kerbside collection of mixed waste is on the uprising, both packaging and non-packaging plastic waste is sorted by polymer. ROAF wants to collect and sort all plastic waste (packaging and non-packaging) by polymer type. The issue of separating plastic items with potential hazardous substances has so far not been discussed to a large extend (Fossum, 2014).

In Denmark it is common to source-separate plastic waste at recycling centers. The plastic types include both packaging and nonpackaging plastics, but in practice the majority of the plastic waste collected is non-packaging.

Combined collection of packaging and non-packaging waste exists in other parts of the EU. Compilation of knowledge on how problems with introducing hazardous substances have been tackled, as well as communication with responsible actors for such systems, could facilitate the work forward.

\section{Economical issues:}

Combined collection of packaging and non-packaging plastics would need to be administratively and legislatively investigated as non-packaging plastic is not covered by producer responsibility and the collection and/or recycling not covered by packaging fees. Some sort of arrangement between municipalities and EPR organisations are probably the less complicated way, and legislative changes avoided. This was also the conclusion from Naturvårdsverket (2009), where an extended producer responsibility to also cover non-packaging plastic waste was evaluated, but not seen as a realistic option. One of the drawbacks identified was that an extended producer responsibility would need a definition of what a plastic item is. This is complicated even for packaging. The most viable solution was considered to be an arrangement on a voluntary basis between municipalities and EPR schemes to enable combined collection.

\subsubsection{Increased collection by sorting collected mixed waste}

The more waste fractions (packaging fractions, food waste and residual waste) that can be collected in the same bin, the less the collection system relies on the consumers willingness to source-separate their waste in a certain manner. However, both the existing and planned Norwegian central sorting facilities for mixed waste still relies on source-separation of food waste, paper and cardboard, glass and metal packaging, textiles, garden waste, hazardous waste, as well as WEEE. Thus, only the plastic packaging is left with the residual waste. It should be emphasized that 
even though the plastic packaging is collected together with residual waste, the households are encouraged to rinse and dry their plastic packaging waste.

Until now, the annual collected and sorted plastics volume at the ROAF central sorting plant has been monitored and calculated to be 13.5 kg per inhabitant (Brevik, 2014). As already emphasised, this amount represents sorted and clean secondary plastic raw material, ready to be sent directly to recycling plants without any further sorting requirements. Thus, the amount of $13.5 \mathrm{~kg}$ per inhabitant equals the collected amount of $14.7 \mathrm{~kg}$ per inhabitant from a source sorting system in Norway when taking into account that the source sorted plastics in average contain about 9.2\% pollution (Grønt Punkt Norge, 2014b). This collection rate at ROAF therefore equals the collection rate achieved from the very best existing kerbside system in Norway or about two times the average collection rate from the existing Norwegian kerbside systems (7.1 kg per inhabitant).

It is recommended to follow the operation of the new sorting facilities in order to investigate and document the collected and the quality of the sorted amounts as well as potential positive and negative synergies with the other waste types. This will contribute to valuable information and background data necessary to create the future waste collection and treatment systems. Analyses of the composition of both input and output residual waste to the ROAF plant have been conducted. However, the results are not yet ready, but will be available for further investigation. According to the predicted mass flow analyses (Fossum, 2014), about $60 \%$ of the total waste $(35,000$ ton) being fed into the plant (food waste and residual waste) is supposed to be incinerated. Thus, $40 \%$ of the total input is supposed to be recycled/biologically treated. These amounts are represented by the following flows: food waste $(23 \%)$, metals $(3 \%)$, plastics $(9 \%)$ and paper $(6 \%)$.

Currently, the plant does not have any specific requirements/maximum values for amounts of food waste or other waste types that should have been source-separated from the residual waste.

According to Tomra (2014) and ROAF (Brevik, 2014), there is no difference in market prices between plastic sorted at a central sorting plant for MSW and plastics from conventional sorting facilities sorting source-separated plastics. Potential drawbacks for central sorting may be the economical issues as the plants require large investments and cooperation between municipalities and producer responsibility organisations. However, according to the intermunicipal companies IVAR (one of the owners of the new sorting plant at the south west coast of 
Norway), the costs of the new plant are calculated to be financed by the estimated $20-25 \%$ reduction in residual waste and thus reduced gate fee costs for incineration, as well as income from sorted waste materials. Another drawback may be that the households become less aware of the value of plastic waste when collected together with residual waste and therefore become less likely to focus on waste minimization in their daily life. However, these aspects need more investigation and research in order to make conclusions.

\section{Economical issues:}

The economical fees received from Grønt Punkt Norge remain the same per kg plastic packaging to sorting compared to other collection systems. The potential withdrawal for the amount of sorted non-packaging plastics will be based upon specific agreements between ROAF and Grønt Punkt Norge and estimated based on analyses of the sorted plastics.

\subsubsection{Increased collection of plastic bulky waste}

Plastic bulky waste from households and other MSW sources is not subject to any dedicated collection and recycling systems in the Nordic countries. An increased trend of collecting plastic bulky waste at municipal recycling centrals is thus observed, especially in Sweden and Denmark. Statistics on plastic bulky waste in the Nordic region is scarce, and the potential for increased recycling through increased collection of bulky waste is therefore difficult to estimate. Jensen et al. (2012) roughly estimated the potential amount of plastics in combustible bulky waste in Sweden to around 36,000 tonnes per year.

In the project Guideline and background report for plastic sorting at recycling centres, also part of the overall project Resource efficient recycling of plastic and textile waste, collection of plastic bulky waste has been more deeply looked at. In the draft guidelines (the final guidelines will be published in the beginning of 2015) challenges to increased separate collection of plastic waste (including plastic bulky waste) are explored. The challenges identified and further evaluated were: many versus few fractions, quantity versus quality, transport and how to deal with products containing hazardous substances. The importance of fulfilling requirements with respect to quality and quantity in order to find a market for the plastic waste was furthermore raised (Andersen et al. 2014).

Even though increased collection of plastic bulky waste is still in its infancy, it surely represents an almost unexploited potential. However, statistics on the amounts of generated plastic bulky waste and its composition is needed to further explore this potential. Compilation of 
knowledge and experience from Nordic municipalities collecting plastic bulky waste could help communicating this option, and also facilitate for municipalities thinking of starting up collection of plastic bulky waste. Guidance on what to think about when procuring treatment of the plastic bulky waste could be part of this knowledge base, as well as how to follow-up that the plastic bulky waste is going to recycling, how much of the collected amounts that is rejected and why.

As for non-packaging small plastic items, the risk of introducing undesired hazardous substances into the recycling system by collecting plastic bulky waste needs to be further evaluated. Typical types of substances are plasticizers, colorants, stabilizers, flame retardants, and biocides, which are found in a variety of products dominated by soft and rigid PVC (Hansen et al. 2013). In general, many of the unwanted chemicals found in bulky plastics are substances that have been or are in the process of being phased out or restricted in use, especially in food contact products, toys and children's articles. However, as there is a substantial lag between entry to the market and the end of life phase, many "past" substances will continue to be found in post consumer plastics (Hansen et al. 2013).

\subsection{Flexible sorting and recycling systems}

Plastic is a widely used material, continuously undergoing development in order to find improved features and new areas of utilisation. A current trend in plastic utilisation is the increased use of different additives, nanos and fibres, enabling new and improved material characteristics. The use of bioplastics is also continuously increasing. Due to the development of new additives and the improved features on specific polymers, there may be changes in the utilisation of specific polymers for specific applications, as well as seizure of new market segments. A consequence from this is the change of incoming material composition to the sorting and recycling facilities.

Changes in the material composition may also be caused by e.g. politics; changes in legislation. Increased EPR coverage, for example, may cause change in the material composition.

Future changes in material composition is hard to foresee, why it is of great importance for the sorting and recycling facilities to be able to adapt to changes in the incoming material composition. Sorting and recycling facilities need to be in line with the composition of the incoming material stream at any given time. Thus, when planning new facilities it 
is of great importance to anticipate unpredictable changes in future incoming material streams. Changeable process units and continuous cooperation with material research and development are key features of a flexible recycling system. "Static" sorting processes can hamper the trustworthiness of the collection and recycling systems if efforts to collect plastic waste are not paid off, i.e. if plastic waste collected is not in the end recycled. The changeable processes must be able to absorb changes in the incoming streams, e.g. possibility to sort out a higher number of polymers, fraction sizes, detection of plastic waste containing specific additives and hazardous substances.

The sorting processes also need to be in line with downstream demands. Requirements from recycling companies/product manufacturers need to be taken into account to find a market for the sorted plastic waste. Continuously tightening local and EU legislation may result in new restrictions and increased recycling targets, as well as more efficient processes.

Changes in downstream material demand may occur regardless of the recycling companies/product manufacturers. Politics and political instabilities are impossible to foresee and may cause disorder in the downstream markets. For example the Chinese green fence has reduced the demand for plastic waste, forcing new markets to be found. Currently the Russian trade barriers have resulted in a ban for imports of a wide range of U.S. and European foods; other similar trade barriers may come in the future and affect other goods, such as waste or raw materials.

A feature for several Nordic countries is the geographically uneven division of population. The majority of the population is situated in large cities in the south, whereas northern territories are more sparsely populated. Flexible processes as well as increased plastics recycling could be achieved through either Nordic collaboration (enabling economy of scale) or through the utilisation of mobile sorting plants.

Long-term planning and predictions both upstream and downstream the sorting processes are needed, as well as functioning cooperation throughout the material life cycle. Best would be if the sorting/recycling companies could have some impact on the product design (this is a poorly achieved aim of EPR theory). The producer responsibility could e.g. have different fees for different materials according to recyclability, thus, steering material utilisation towards more homogeneous material streams and increased recycling rates.

Possible consequences of having a recycling system able to adapt to changes in demand of individual waste streams: 
- Increased investment and maintenance costs for flexible processes.

- Increased administrative costs from increased cooperation throughout the material life cycle.

- Lack of public support if the sorting system changes often (as the public/companies also need to adapt to different conditions).

\subsection{Market opportunities}

A well-functioning market where the collected and sorted amounts of plastic waste are absorbed and recycled into new products is a key requirement for higher levels of plastic recycling. The market and the demand for recycled plastics, the final step in the value chain, is a strong driver for increased collection.

Energy recovery is the most common treatment for plastic waste in the EU. The dominating energy recovery is analysed and described by Plastics Europe (see figure below), and the large amount of plastics ending up in incineration and landfills makes out a substantial potential for recycled plastics. Plastics Europe assess that the volume of European plastic waste generation was approximately 26 MT in 2011, and of this 7 MT was recycled, leaving round 19 MT plastics that potentially could be recycled. It is, however, reasonable that the recycling of plastics currently being energy recovered and landfilled requires substantial changes in product design, waste management, and waste policy.

Figure 2. Total Recovery Rate by Country 2011

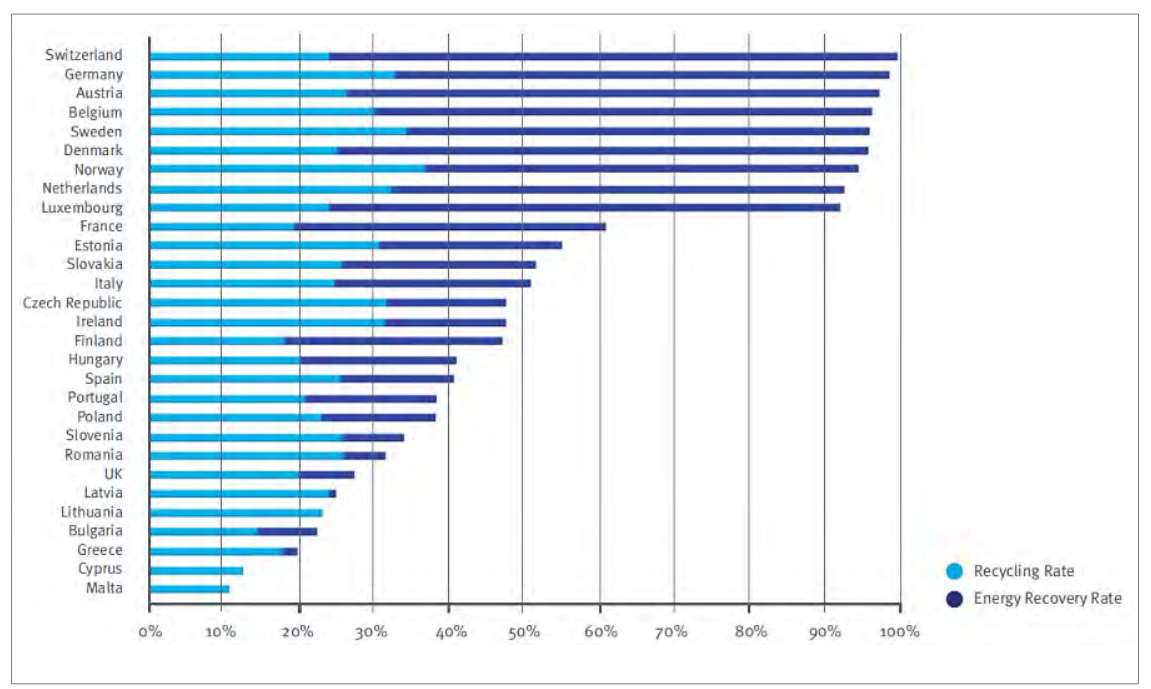

Plastics Europe, 2012. 
Important for the overall environmental impact of plastic collection and recycling is that the secondary plastic raw material substitutes virgin plastics to a high extent, i.e. recycling into products of high quality. Recycling into products of high-quality requires that the collection and recycling systems can provide high-quality secondary plastic raw material to the market. This calls for cooperation and communication in the value chain. The Nordic markets for plastic waste are according to Hennlock (2014) characterised by demands for a relatively high quality of secondary plastics compared to the qualities supplied. Recycled plastic does not always meet the quality specifications that plastic manufacturers of technical high quality plastic products demand.

The use of recycled plastics is influenced by two economic drivers; the price of the recycled polymer compared to virgin polymer, and the cost of recycling compared to alternative forms of acceptable disposal. The price of virgin plastic is in turn influenced by the price of oil. The price of virgin plastics sets the ceiling for prices of secondary plastic raw material as the quality of secondary plastic raw material is typically lower than the quality of virgin plastics (Hennlock, 2014). The prices for secondary plastic raw material are fluctuating. In Figure 3 examples of fluctuations in price for polymers sorted out from plastic packaging waste is shown (WRAP, 2014). During the second workshop held within the project potential users of secondary plastic raw material shared their experience on the fact that prices for secondary plastic raw material in periods have been higher than for primary plastics.

Figure 3. Substantial fluctuations in price, exemplified with British figures

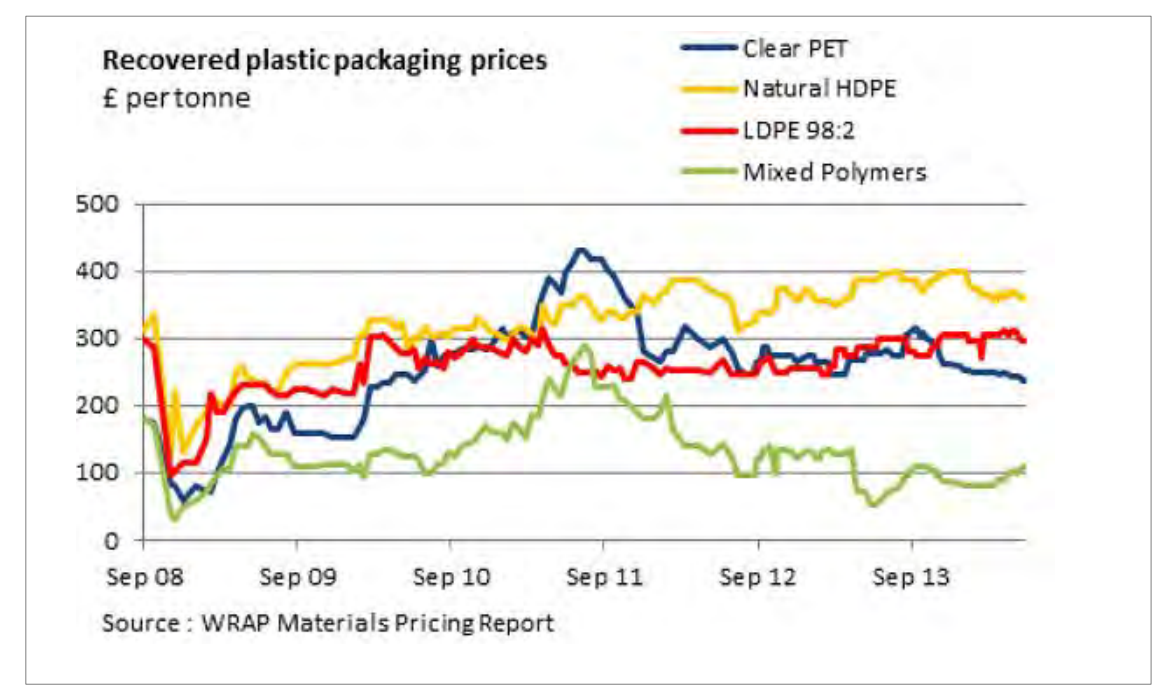

WRAP, 2014. 
Hennlock (2014) finds that major opportunities for increasing recycling of post-consumer plastics are to increase level of information with regard to quality and specifications of recycled plastics. Product manufacturers using recycled plastics need to know what they are buying, and get information similar to the information they receive when buying virgin plastics. This means that sellers of recycled plastics need to provide more information about their products, and possibility to give the buyer quality assurance and this again requires redesign of the plastic products entering the waste stream to enhance recyclability. The buyers of recycled plastics need to know that the supply is continuous and that the quality is not fluctuating. Policy instruments with focus on creating "a pull" towards increased use of recycled plastics could be further evaluated such as including criteria on the use of recycled plastics in public procurement and giving economic incentives/advantages to product manufacturers using recycled plastics.

Recycling of plastics is also driven by production and consumption of plastic products. $40 \%$ of the world's production of plastic products takes place in Asia (24\% in China) why the demand for both primary and secondary plastic raw material is strong. Almost half of the amount of plastic waste collected for recycling in the EU is exported whereof nearly $90 \%$ of the exported amounts go to China, either to China directly or via the Hong Kong SAR. The Chinese demand for affordable secondary plastic raw material to supply the production of plastic products make the EU exports dependent of China. The exported plastic waste is fuelling industrial demand, but in depth details about the fate of the exported plastic waste when it reaches China is not justified by conclusive evidence. Environmental and health aspects related to recycling of plastic waste has not been enough systematically explored. Indirect evidence suggests that domestic plastic waste is of poor quality compared to the imported material why the imported material is used for higher quality product manufacturing (Velis, 2014).

Even though the collection and recycling systems for plastic in the EU to a large extent depend on export to third countries, the other half of the collected amounts of plastic waste for recycling stays in the EU. Learning and sharing good examples from existing product manufacturers in the Nordic countries, and in the EU, using recycled plastics today could inspire and encourage to local market, decreasing the dependence on exports. Deepened knowledge and communication of the knowledge about plastic manufacturing in the Nordic countries and in the EU could help estimating the potential use of secondary plastic raw material on the local markets. On a Nordic level such 
knowledge sharing could be boosted by increased Nordic cooperation (see chapter 2.4).

\subsection{Nordic cooperation}

The Nordic countries have similar and mutual markets for plastic products, with several actors active in all countries. Still the plastic waste management differs significantly between the countries although some waste management actors are active in more than one Nordic country, and a co-operation for plastic recycling is already established between Sweden and Norway.

The main problem with the Nordic markets is the small scale of the markets and high level of import, and thus authorities and recyclers have difficulty to influence the designers/producers of plastic products in order to achieve better recyclability of the products. Impact on product design and recyclability could be achieved through market cooperation across the material value chain, with authorities, and across borders.

The Nordic cooperation for plastics recycling can either be on a practical level with only a few recycling facilities treating the pre-sorted plastic waste from all Nordic countries; or it can be more based on knowledge exchange including information sharing and benchmarking between the countries. Knowledge exchange could hopefully provide conditions and pave the way to cooperation on a more practical level.

A middle road between the practical and knowledge exchange cooperation could be the development of a material exchange platform facilitating the Nordic market for secondary plastic raw material. Such platforms are seen in Europe. One example is Plasticker, ${ }^{5}$ a market place for material and machinery exchange. Virgin plastics, recyclates and plastic waste are traded. The market place can be used by any company or organisation free of charge. There are no sign-up, insertion or transaction fees. The market place is financed by banner ads, job advertisements and paid company profiles (Plasticker, 2014).

${ }^{5}$ www.plasticker.de 


\subsubsection{Nordic cooperation on a practical level}

One of the main problems with municipal plastic recycling in the Nordic countries is the widespread geography and the low volumes, which makes it hard to get the collection and recycling economically profitable. Through practical cooperation the Nordic countries could achieve economy of scale, allowing for sorting and recycling more within our own markets. In order to facilitate Nordic cooperation in practice, the legislation regarding waste transfers must allow for continuous transfers between Nordic countries.

Further supporting the Nordic plastic recycling cooperation would be the certification of secondary raw materials. All Nordic countries have high safety requirements for products, and a joint standard development for recovered plastics could be made as a Nordic cooperation. The same certification with high standards should apply for all Nordic countries, allowing the secondary raw material to reach a high status and demand on both Nordic and international markets. In order to support the certification of secondary plastics, the legislation on utilization of recycled materials must support the certified materials. These standards could also be introduced for implementation in all EU member countries. As first to implement these standards, the Nordic recyclers would have a head start on the European markets.

A practical Nordic cooperation should be market driven, where the actors are given both needed administrative and financial support to expand their activities, allowing e.g. to recycle larger volumes of plastics. Sorting facilities might need investments in order to guarantee a certain quality of the product. Due to complicated bureaucracy for international waste transfers, the actors may need some administrative support to get the cooperation started.

Although secondary plastics can replace virgin plastics for several purposes, it is also important to find new products which can use $100 \%$ secondary plastics or a share of secondary sources. Cooperation with Nordic designers and producers (e.g. IKEA) could result in increased markets for the secondary raw materials. If implementing cooperation with large producers, the capacity should be much higher than currently in the Nordic countries, why collection and recycling rates would need to be increased. 


\subsubsection{Nordic cooperation based on knowledge exchange}

Cooperation based on knowledge exchange could aim at creating a Nordic platform where users of recycled plastics, sorters, and representatives from municipalities and EPR organisations exchange information. This platform could serve as a best-available-technology (BAT) platform where countries learn from each other or as a networking platform to facilitate practical cooperation and enabling the players of the value chain to influence each other as well as the administration. It seems like communication between the different activities in the value chain is not working efficiently and that a lot could be gained by "connecting the dots". What can different actors do/not do/would like to do? Nordic cooperation could possibly work as a catalyst towards this connection. A challenge with knowledge exchange and creation of a platform is to convince the involved actors that there are benefits from taking part, as involvement could be regarded as sharing trade secrets.

Increased cooperation could also aim at a common Nordic approach to calculate national recycling rates - to facilitate benchmarking between the Nordic countries. This forum could be arranged by an independent organisation also acting as an umbrella organisation for the EPR organisations. Other possible tasks for such a forum could be to develop information to households about the benefits of plastics recycling based on Nordic knowledge to increase the trustworthiness of plastic recycling. The forum could also initiate improved dialogue between contracted sorting facilities/EPR organisations and their registrerad producers to share knowledge about products that due to their design are not possible to recycle in the existing recycling system. In order to aim for higher recycling rates there is probably need for either raised demands on producers, raised demands on the contracted sorting facilities, or possibly on the two of them.

\subsubsection{Proposals for implementing Nordic cooperation}

The creation of a Nordic cooperation platform requires stakeholder involvement already in the planning phase; the specific interests and benefits for the stakeholders along the whole value chain need to be mapped in order to create the preconditions for a successful cooperation. The aim of the cooperation is to benefit the stakeholders along the value chain, while also supporting increased collection and recycling of plastic waste in the Nordic countries and supporting the utilisation of secondary raw materials. 
Funds for the arrangement of the platform could be initialised as project financing and continue through member fees. In order to attract paying members the cooperation platform must benefit its members through e.g. increased markets, beneficial information exchange etc. Partners from across the value chain should be invited to the platform, including designers, production industry, waste management companies, processers and recyclers, public sectors (national/regional/ local) and consumer representatives.

The EC H2020 Waste-4d-2015 calls for the creation of a raw material partnership through a multi-stakeholder platform with partners across the value chain. Such a project would enable the creation of the Nordic cooperation platform focusing on information exchange with thorough stakeholder involvement and influence, enabling to find the needs and benefits throughout the plastic value chain. To maximize the chances for H2020 financing, a detailed and well edited application with stakeholder input must be written. As the application would be pan-Nordic, the financing for writing the application could be applied from the NCM or directly from NWG. 


\section{Conclusions}

There is great potential in increasing collection and recycling of plastic waste from households and other MSW in the Nordic region. The project group has identified the following future solutions in order to improve collection and recycling of plastic waste aiming for higher recycling rates.

\section{Increased collection of plastic waste}

A condition to increase recycling of plastic is to collect more of the generated plastic waste in the dedicated collection and recycling systems, and thus avoid plastic waste in waste fractions to incineration.

Key to increased collection seems to be availability for the consumers together with communication and transparency. Practical options are plentiful, and local circumstances require different solutions. Less focus on packaging and more focus on plastic would be beneficial for the overall collection and recycling of plastic waste. Such a collection system would require further evaluation. With the current market situation increased availability would result in increased costs, and could possibly be financed with adjusted packaging fees.

\section{Fluctuations in material composition and the development of a flexible recycling system}

Sorting and processing of plastic waste needs to be in line with the incoming material composition and produce secondary plastic raw material that substitute virgin plastics to the highest extent possible. Recycling into products of high-quality requires collection and recycling systems that provide high-quality secondary plastic raw material to the market. This calls for cooperation and communication in the value chain.

Plastic continuously undergo development in terms of content (polymers and additives) and material characteristics, which impose a challenge for the sorting and recycling processes as it causes changes in the incoming material composition. Changeable process units and continuous cooperation with material research and development are key features of a flexible recycling system. Possible consequences of having a more flexible recycling system are increased costs - both investment, maintenance, and administrative ones. 


\section{Market opportunities}

The market and the demand for recycled plastics, the final step in the value chain, is a strong driver for increased collection. The secondary plastic raw material should substitute virgin plastics to a high extent to reach as low overall environmental impact of plastic collection and recycling as possible. Recycling into products of high-quality requires collection and recycling systems that provide high-quality secondary plastic raw material to the market. This calls for cooperation and communication in the value chain. Policy instruments with focus on creating "a pull" towards increased use of recycled plastics could be further evaluated, such as including criteria on the use of recycled plastics in public procurement and giving economic incentives/advantages to product manufacturers using recycled plastics.

Recycling of plastics is also driven by production and consumption of plastic products. Almost half of the amount of plastic waste collected for recycling in the EU is exported. The export is heavily dependent on export to China. In depth details about the fate of the exported plastic waste when it reaches China is not justified by conclusive evidence. Such deepened knowledge would increase transparency, and in turn the trust in recycling of plastics. The other half of the collected amounts of plastic waste for recycling stay in the EU. Learning and sharing good examples from existing product manufacturers in the Nordic countries, and in the $\mathrm{EU}$, using recycled plastics today could inspire and boost the local market, decreasing the dependence on exports and the discrepancy between the quality produced and the quality needed.

\section{Nordic cooperation}

All proposed future solutions to increase Nordic plastic recycling could benefit from more extensive Nordic cooperation. Cooperation at two levels would be possible: on a practical level and based on knowledge exchange including information sharing and benchmarking between the countries. Knowledge exchange would hopefully pave the way and provide conditions for more practical Nordic cooperation. Practical cooperation between the Nordic countries could lead to economy of scale, allowing for sorting and recycling more within the local markets. 


\section{References}

Andersen L, Jacobsen J B, Lundqvist P, Johansen M, Kirkeby J (2014) Plastic Sorting at Recycling Centres (DRAFT GUIDE), Nordic Working Papers, http://dx.doi.org/ 10.6027/NA2014-911

Avfall Norge (2014). Status for energiutnyttelse av avfall i Norge. Report 3/2014. http:// www.avfallnorge.no/pop.cfm?FuseAction=Doc\&pAction=View\&pDocumentId=53746

Avfall Sverige (2011). Nationell kartläggning av plockanalyser för hushållens kärl- och säckavfall. Aktuella resultat och metodik. Rapport U2011:4.

Avfall Sverige (2009). Handbok för avfallsutrymmen. Råd och anvisningar för transport, förvaring och dimensionering av hushållsavfall. http://www.avfallsverige.se/ fileadmin/uploads/Rapporter/Handbok_f\%C3\%B6r_avfallsutrymmen/ handbokAvfallsutrymmen.pdf

Bio Intelligence Service (2011). Plastic waste in the Environment. Specific contract 07.0307/2009/545281/ETU/G2 under Framework contract ENV.G.4/FRA/2008/0112. http://ec.europa.eu/environment/waste/studies/pdf/plastics.pdf

Brevik, Ø (2014). Managing Director at ROAF, Telephone June 172014.

Dahlén L, Vukicevic S, Tapper M (2013). Återvinning av plast från hushållsavfall. Insamlingsresultat och kvalitet av källsorterad plast 2013. Plastkretsens stiftelse för forskning.

Dvorak R, Kosior E, Moody L (2011). Development of NIR Detectable Black Plastic Packaging. WRAP Final Report. http://www.wrap.org.uk/sites/files/wrap/ Recyclability\%20of\%20black\%20plastic\%20packaging.pdf

Envac (2009). Vakuumteknologi. http://www.envac.se/produkter_och_tjanster/ var_teknik/vakuumteknologi

Eskilstuna Energi \& Miljö (EEM) (2012). Interview with Mikael Nilsson within the project Reco Baltic 21Tech.

FCG Consulting (2010). Uuden jätelainsäädännön mukaisten keräysverkostovaatimusten kustannusvaikutukset pakkausten jätehuollossa. (Cost effects arising from the requirements of Finland's new waste legislation on the collection network of packaging waste). Report ordered by the Ministry of Environment 1907-P11168.

Fossum, T. R (2014): Interview /dialogue with Tom Roger Fossum, Constituted Managing Director at ROAF, October 222014.

Foster S (2008). Domestic Mixed Plastics Packaging Waste Management Options - An assessment of the technical, environmental and economic viability of recycling domestic mixed plastics packaging waste in the UK. WRAP Final report.

Förpacknings- och tidningsinsamlingen AB (FTI) (2014). Personal communication with Mia Steinbach.

Grønt Punkt Norge, 2014a. Data sheet: Statistikk plastemballasje fra Husholdninger of May 14th 2014

Grønt Punkt Norge, 2014b. Data sheet: Pollution statistics 2012 and 2013 of x and October 2014

Gällivare kommun (2014). Personal communication with Gun-Marie Hannu. 
Hage, $\mathrm{O}$ and Söderholm, $\mathrm{P}$ (2008). An econometric analysis of regional differences in household waste collection: The case of plastic packaging waste in Sweden. Waste Management, Volume 28, Issue 10, Pages 1720-1731

Hansen et al (2013) Hazardous substances in plastic, Rapport TA-3017, Klima- og Forurensnings-Direktoratet. http://www.miljodirektoratet.no/no/Publikasjoner/ Publikasjoner/2013/Februar/Hazardous_substances_in_plastic_materials/

Hedenstedt A (2014). Planeringsprojekt: Gemensam utformning av avfallskärl för källsortering i stadsmiljö. SP Sveriges Tekniska Forskningsinstitut.

HEMAB (Härnösand Energi och Miljö AB). Personal communication with Cathrine Edholm.

Hennlock (2014). On the Design of Policy Instruments for Efficient Waste Plastic Recycling - A Review of Nordic Perspectives [Draft 2014-09-01]. IVL.

Hopewell et al (2009) Plastics Recycling: Challenges and opportunities. Philosophical Transactions of the Royal Society B: Biological Sciences, 364(1526), 2115-2126

Keep Sweden Tidy (2014). Rapport från kusträddarna - Om skräpet på den svenska västkusten.http://www.hsr.se/sites/default/files/kustraddarna2014_rapport_lagu pplost.pdf

Keep Sweden Tidy, Keep the Archipelago Tidy Association, Keep the Estonian Sea Tidy FEE Latvia (2013). Final report of Baltic Marine litter projekt MARLIN - Litter monitoring and raising awareness. http://www.videsfonds.lv/documents/final-report.pdf

Kemikalieinspektionen (Swedish Chemical's Agency) (2011). Kemikalier i varor Strategier och styrmedel för att minska riskerna med farliga ämnen i vardagen. Rapport nr 3, 2011.

Lyng, K.-A. and Modahl, I. S. (2011): Livsløpsanalyse for gjenvinning av plastemballasje, fra norske husholdninger. OR 10.11.

Mail A, Morrish L, Morton R, Myles N and Wilkinson S (2010). Good practice of Near Infrared sorting of plastic packaging. WRAP technical report.

Moliis, K., H. Dahlbo, R. Retkin and T. Myllymaa. 2012. Pohjois-Suomen pakkausjätteiden hyödyntäminen: Elinkaaren aikaiset ympäristö- ja kustannusvaikutukset. Ympäristöministeriön raportteja 26/2012.

Modahl, I.S., Baxter, J., Lyng, K.-A., Arnøy, S., and Raadal, H.L. (2013): The importance of data specificity in climate accounting of waste management systems. Poster presented at the LCM Life Cycle Management 2013 conference, Gothenborg, August 28th 2013. Extended summary: http://conferences.chalmers.se/index.php/LCM/ LCM2013/paper/view/725/323

Naturvårdsverket (2009). System för insamling av hushållsavfall i materialströmmar Rapport 5942, 2009.

Optibag (2014). Optical sorting. http://www.optibag.com/technical_data/opticalsorting

Plasticker (2014). Personal communication with Rolf Juffenbruch.

Plastics Europe (2012). Plastics - the Facts 2012 An analysis of European plastics production, demand and waste data for 2011,

Surahammars KommunalTeknik AB (2014). Personal communication with Per Andersson.

TOMRA (2014). Personal communication with Jürgen Priesters, Business Development Manager - Segments.

Velis C.A. (2014). Global recycling markets - plastic waste: A story for one player China. Report prepared by FUELogy and formatted by D-waste on behalf of International Solid Waste Association - Globalisation and Waste Management 
Task Force. ISWA, Vienna, September 2014.

WRAP (2014). Market snap shot - July 2014. http://www.wrap.org.uk/sites/files/ wrap/Market_Snapshot_July_2014.pdf).

WRAP (2009). Choosing the right collection system. http://www.wrap.org.uk/sites/ files/wrap/Choosing\%20the\%20right $\% 2$ recycling\%20collection $\% 20$ system.pdf WRAP (2010). Environmental benefits of recycling - 2010 update. http://www.wrap. org.uk/sites/files/wrap/Environmental_benefits_of_recycling_2010_update.3b174d5 9.8816.pdf 



\section{Appendix 1: Definitions used in the report}

\section{Bring systems}

Manned or unmanned drop-off points for public use where households are able to discard plastic packaging waste, and commonly several other waste fractions.

\section{Kerbside collection}

The meaning of kerbside collection is not explicit, but the definition chosen within the project is that kerbside collection is a collection system where households are able to discard their plastic packaging waste within the boundaries of the estate. Kerbside collection systems are as opposed to bring systems not for public use.

\section{Other municipal waste sources (msw)}

Other municipal waste sources commonly refer to waste generated by other sources than households, but with the same composition as household waste. In some Nordic countries the term household waste includes "similar waste" from businesses. Examples of similar waste are waste generated in canteens or in toilets and bathrooms.

\section{Plastic packaging waste}

"All products to be used for the containment, protection, handling, delivery and presentation of goods, from raw materials to processed goods, from the product to the user or the consumer", as stated in the Packaging Directive.

\section{Source-separation}

There are different levels of source-separation, but they all have in common that the households make an effort to sort their waste in a certain manner. Plastic packaging waste can either be source-separated into a single stream, e.g. into a fraction meant to contain plastic packaging waste only or into a fraction containing other recyclable materials or plastic waste other than packaging. 



\section{Sammanfattning}

Future solutions for Nordic plastic recycling är ett resultat av projektet Improvements in existing collection and recycling systems for plastic waste from households and other MSW sources, som har initierats av Nordiska avfallsgruppen (NAG). Projektet har genomförts av fem organisationer som representerar olika del av Norden: IVL Svenska Miljöinstitutet (projektledare), Østfoldforskning (Norge), VTT Technical Research Centre of Finland (Finland), Aalborg Universitet (Danmark) och Environice (Island).

Potentialen att öka insamlingen och materialåtervinningen av plast från hushåll och andra kommunala avfallskällor i Norden är stor. Projektgruppen har identifierat följande framtida lösningar mot mer insamling och materialåtervinning av plastavfall och ökade återvinningsgrader.

Rapporten ingår i de nordiska statsministrarnas initiativ för grön tillväxt: "Norden - ledande i grön tillväxt" - läs mer i webbtidningen "Green Growth the Nordic Way" på adressen www.nordicway.org eller www.norden.org/ sv/tema/green-growth

\section{Ökad insamling genom ökad tillgänglighet}

En förutsättning för att öka materialåtervinningen av plast är att samla in mer av det genererade plastavfallet i insamlings- och återvinningssystemen och därmed undvika att plastavfall hamnar i brännbara avfallsfraktioner. Nyckeln till ökad insamling verkar vara tillgänglighet för konsumenterna. Högre tillgänglighet kan åstadkommas genom fastighetsnära insamling, genom ett tätare nät av återvinningsstationer och genom mindre avlämningsplatser i stadsmiljö. Insatser för att ge andra kommunala källor än hushåll (såsom mindre företag) ökad tillgänglighet till praktiska lösningar skulle också kunna bidra till att mer av det plastavfall som genereras samlas in till materialåtervinning. Kombinationer av lösningar med fokus på ökad tillgänglighet som tar hänsyn till lokala förhållanden krävs, lösningar som inkluderar både källsorterat plastavfall och plastavfall som sorteras ut från restavfall. Med rådande marknadssituation kommer ökad tillgänglighet resultera i ökade kostnader för insamlings- och återvinningssystemen, och skulle eventuellt kunna finansieras med höjda förpackningsavgifter. 


\section{Mindre fokus på förpackningar och mer fokus på plast}

Mängden avfall i form av mindre plastartiklar (ej förpackningar) som genereras är liten jämfört med mängden plastförpackningar som uppstår. Kombinerad insamling av förpackningar och icke-förpackningar av plast kan vara fördelaktigt ur många aspekter. Mindre plastartiklar källsorteras till viss mån redan bland plastförpackningarna och det är tydligt att många konsumenter inte är medvetna om skillnaden på förpackningar och icke-förpackningar. Ett insamlingssystem baserat på material utmanas av det faktum att icke-förpackningar av plast är en mer heterogen ström än plastförpackningar, både i förhållande till antal polymerer som används och i relation till innehåll av oönskade potentiella farliga ämnen, effekter som bör utvärderas ytterligare. Även administrativa och rättsliga aspekter skulle behöva utvärderas, liksom potentiella effekter på kvaliteten hos den sekundära plastråvaran.

\section{Flexibelt sortering- och återvinningssystem}

Sortering och bearbetning av plastavfall behöver vara i linje med den inkommande materialsammansättningen och producera sekundär plastråvara som möjliggör substitution av jungfrulig plast till högsta möjliga grad. "Statiska" sorteringsprocesser kan hämma trovärdigheten för insamlings- och återvinningssystemen om ansträngningen att samla in plastavfall inte lönar sig, det vill säga om plastavfall som samlas in i slutändan inte går till materialåtervinning. Utbytbara processenheter och kontinuerligt samarbete med forskning och utveckling är viktiga inslag i ett flexibelt återvinningssystem. Ansvaret för att säkra att sorteringsprocesserna är i linje med nedströms efterfrågan bör vara uppdelat på aktörer i värdekedjan, t.ex. att sorterings- och återvinningsföretag kan inverka på produktdesign.

\section{Marknadsmöjligheter}

Marknaden och efterfrågan på återvunnen plast, det sista steget i värdekedjan, är en stark drivkraft för ökad insamling. För att åstadkomma en hög miljönytta är det viktigt att den återvunna plasten ersätter jungfrulig plast i stor utsträckning. Det kräver att insamlings- och återvinningssystemen kan tillhandahålla högkvalitativ sekundär plastråvara till marknaden, vilket i sin tur kräver samarbete och kommunikation i värdekedjan. Vidare är det viktigt med öppenhet i värdekedjan; tillverkare som använder återvunnen plast måste veta vad de köper och få information likvärdig den de får när de köper jungfrulig plast. 
Användningen av återvunnen plast påverkas av två ekonomiska drivkrafter; priset på återvunnen polymer jämfört med jungfrulig polymer och kostnaderna för materialåtervinning jämfört med andra behandlingsformer för plastavfall. Styrmedel med fokus på att skapa drivkrafter mot ökad användning av återvunnen plast skulle kunna utvärderas, till exempel kriterier vid offentlig upphandling som gynnar användning av återvunnen plast och ekonomiska incitament/fördelar för produkttillverkare som använder återvunnen plast.

Materialåtervinning av plast drivs även av produktion och konsumtion av plastprodukter. Nästan hälften av plastavfallet som samlats in för materialåtervinning inom EU exporteras. Merparten av de exporterade mängderna går till Kina och det finns inte tillräcklig kunskap om vad som händer med plastavfallet där. Fördjupad kunskap skulle öka insynen och transparensen i värdekedjan. Att visa goda exempel på produkttillverkare som använder återvunnen plast inom EU och Norden skulle kunna inspirera till ökad användning inom de lokala marknaderna, vilket i sin tur skulle minska beroendet av export.

\section{Nordiskt samarbete}

Samtliga föreslagna framtida lösningar för att öka insamlingen och materialåtervinningen av plast i Norden kan dra nytta av mer omfattande nordiskt samarbete. Samarbete på två nivåer skulle vara möjligt: på en praktisk nivå och på en nivå som bygger på kunskapsutbyte mellan länderna. Kunskapsutbyte skulle förhoppningsvis bana väg och ge förutsättningar för mer praktiskt nordiskt samarbete. Praktiskt samarbete mellan de nordiska länderna skulle kunna leda till ökad sortering och materialåtervinning inom de lokala marknaderna.

Kommunikation mellan olika aktiviteter/aktörer i värdekedjan verkar inte fungera effektivt. Genom att "koppla ihop trådarna" skulle det bli tydligare vad de olika aktörerna kan göra/inte göra/skulle vilja göra, och där samarbete skulle vara fördelaktigt. En nordisk nätverksplattform med intressenter i hela värdekedjan skulle kunna skapa förutsättningar för ökad kommunikation och framtida samarbete. Möjliga uppgifter för ett sådant forum skulle kunna vara att utveckla gemensam information till hushållen om fördelarna med plaståtervinning baserade på nordisk kunskap, sträva efter en gemensam nordisk strategi för att beräkna nationella återvinningsgrader för att underlätta jämförelse mellan de nordiska länderna samt att inleda en förbättrad dialog mellan kontrakterade sorteringsanläggningar/producentansvarsorganisationer och deras registrerade producenter för att utbyta kunskap om vilka produkter som på grund av sin konstruktion inte är möjliga att materialåtervinna i de befintliga systemen. Nätverket skulle kunna arrangeras av en oberoende organisation som 
också fungerar som en paraplyorganisation för producentansvarsorganisationerna. Medel för att organisera plattformen skulle inledningsvis kunna vara projektfinansierad och därefter finansierat genom medlemsavgifter. Aktörer från hela värdekedjan bör bjudas in till plattformen, inklusive designers, produkttillverkare, avfallshanteringsföretag, sorterings- och återvinningsföretag, offentlig sektor (nationell/regional/lokal) och representanter för konsumentsidan. 
Nordic Council of Ministers

Ved Stranden 18

DK-1061 Copenhagen K

www.norden.org

\section{Future solutions for Nordic plastic recycling}

Future solutions for Nordic plastic recycling contains suggestions on how to collect and recycle more of the generated plastic waste from households and other MSW sources in the Nordic region. The solutions suggested are focused on providing higher availability to collection systems, to focus less on packaging and more on plastic, to have flexible sorting and recycling systems, and to pave the way for a well-functioning, transparent market for recycled plastics that absorbs the collected material. More extensive Nordic cooperation, both on a basis of knowledge exchange and on a practical level, is believed to favour Nordic plastic collection and recycling.

The report is part of the Nordic Prime Ministers' green growth initiative: "The Nordic Region - leading in green growth". Read more in the web magazine "Green Growth the Nordic Way" at www.nordicway.org or at www.norden.org/greengrowth

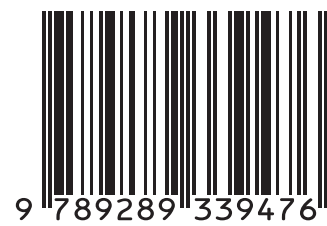

